\title{
A mikroRNS-ek jelenléte vesetumorokban és lehetséges diagnosztikai-prognosztikai szerepük
}

\author{
Szegedi Krisztián dr.2, Szabó Zsuzsanna dr., Flaskó Tibor dr.', \\ Halmos Gábor dr.
}

'Debreceni Egyetem, Gyógyszerésztudományi Kar, Biofarmácia Tanszék, Debrecen (igazgató: Halmos Gábor dr.), Debreceni Egyetem, Klinikai Központ, Urológiai Klinika, Debrecen (igazgató: Flaskó Tibor dr.)

\author{
Levelezési cím: \\ Prof. dr. Halmos Gábor Pharm. D. PhD \\ Debreceni Egyetem, \\ Gyógyszerésztudományi Kar, \\ Biofarmácia Tanszék \\ 4032 Debrecen, Nagyerdei krt. 98. \\ E-mail cím: \\ halmos.gabor@pharm.unideb.hu; \\ kszegedi81@yahoo.com
}

\begin{abstract}
ÖSSZEFOGLALÁS
A vesedaganatos betegek száma világszerte emelkedik. Noha a vesekarcinóma patológiája és biológiája egyre felderítettebbé válik, teljesen sikeres sebészeti, onkológiai, radiológiai megoldás vagy eredményesen alkalmazott célzott terápiás kezelés továbbra is csak korlátozott lehetőségeket biztosít. Emiatt a vesetumoros betegek prognózisa rossz. A késői felismerés, a tumor-heterogenitás és legföképpen a korai diagnózist segítő molekuláris biomarkerek hiánya miatt a betegség diagnosztikája és kezelése jelentős hátránnyal bír.

Új biomarkerek azonosítása a daganatkutatás egyik fontos feladata, a diagnosztika hatékonysága, a prognózis megítélése és az eredményesebb gyógykezelés érdekében. Ebben a tekintetben ígéretesnek mutatkozik olyan biomarkerek azonosítása, amelyeknek mintázata tumoros szövetekben eltérő a normálszövethez képest. Genomiális és proteomika szinten is egyre inkább bővül az adatbázisok száma a tumorspecifikus markereket illetően. A szakirodalomban körülbelül egy évtizedre vetíthető vissza a mikroRNS-ek (miR) megjelenése, amelyek mintázatának leírásával ma már akár egy-egy daganattípus is jellemezhető. Noha az utóbbi években a publikációk száma egyre bővül, a miR-ekre vonatkozó ismeretek nem eléggé elterjedtek az olvasók/szakemberek körében, magyar nyelvű összefoglaló pedig igen korlátozottan található. Ebben a közleményben arra törekszünk, hogy egy összesítő képet adjunk a miR-ek vesetumorok kialakulásában betöltött funkcionális szerepéröl, és egyúttal hangsúlyozzuk a miR-ek lehetséges diagnosztikai és prognosztikai szerepét is a vesedaganatos betegségek kapcsán.
\end{abstract}

KULCSSZAVAK: VESETUMOR, MIRNS, DIAGNÓZIS, PROGNÓZIS, TERÁPIA

\section{Expression of microRNA and their possi- ble role in diagnosis and prognosis of renal cell carcinoma}

\section{SUMMARY}

Renal cell carcinoma accounts for approximately $3 \%$ of cancers in adults as well as $85 \%$ of all primary malignant kidney tumours. It is the third most common urological cancer after prostate and bladder cancer, but it has the highest mortality rate of more than $40 \%$. Apart from surgery, it is both chemotherapy and radiotherapy resistant. Early detection and appropriate follow-up of the patients may influence the prognosis of the disease. It is necessary, therefore, to improve our understanding of renal cell carcinoma pathogenesis, identify new biomarkers enabling prediction of early metastasis after nephrectomy, and develop new targeted therapies.

MicroRNAs are small, non-coding RNAs that have an important role in the regulation of carcinogenesis pathways. Tumour tissue expresses miRNAs differentially compared to corresponding normal tissue, and they regulate important breakpoints during carcinogenesis. There is increasing evidence in the literature suggesting that they might be associated with the development of renal cell carcinoma, and the expression profiles of miRNAs are believed to be more informative and accurate for classifying kidney cancer. In the future some of them can be potential novel biomarker candidates for the diagnosis and treatment of human cancers including renal cell carcinoma. In this paper we aimed to summarize the information about the functional role of miRNAs in the development of renal cell carcinoma.

KEYWORDS: RENAL CELL CARCINOMA, MIRNA, DIAGNOSIS, PROGNOSIS, THERAPY 


\section{Bevezetés}

A mikroRNS (miR) rövid, egyszálú, nem kódoló, körülbelül 1925 nukleotid hosszúságú RNS-ek. Mióta az első miR-t (lin4) 1993-ban Lee és munkatársai Caenorhabditis elegans-ban felfedezték, azóta több mint 1800 egyedi humán miR-t identifikáltak, amelyek száma folyamatosan növekvő tendenciát mutat. Megfigyelésük szerint a lin-4 szekvenciája komplementer a lin-14 gén 3' nem transzlálódó régiójával (UTR), feltehetőleg a lin-14 mRNS transzlációját szabályozhatja az antiszensz RNSRNS kölcsönhatás révén $(1,2)$.

Becslések szerint a humán gének 30\%-a miR-ek által szabályozottak. A target (cél) génjeik 3' UTR régiójában lévő komplementer szekvenciákhoz kötődnek. Szabályozni képesek az mRNS transzkripcióját a célgén mRNS-ének hasítása vagy szövetspecifikus fehérjeszintézis repressziója által (1-3). Specifikus target gének expresszióját szabályozva, kritikus elemei a celluláris funkcióknak. Ennek köszönhetően elengedhetetlen részét képezik a sejtproliferáció, differenciálódás, metabolikus jelátvitel, apoptózis folyamatának (1, 2). Jelenlegi kutatások szerint számos miR expressziója módosul malignus megbetegedésekben - vagy túlzottan, vagy csökkent mértékben expresszálódnak - ami annak a gondolatát veti fel, hogy tumor

\section{1. ÁBRA: MIRNS BIOGENEZISÉNEK FOLYAMATA}

Forrás: http://www.sabiosciences.com/pathwaymagazine/minireview/ mr110715.php (DGCR8: DiGeorge syndrome critical region gene 8, TRBP: TAR RNA binding protein, Ago 2: Argonauta fehérje 2, miRRISC: RNS-indukálta csendesítő komplex, Dicer: RNáz motívummal ellátott endoribonukleáz vagy helikáz, amelyet a humán DICER1 gén kódol, az RNS-polimeráz III család tagja, Exportin-5: egy fehérje, amelyet a humán XP05 gén kódol

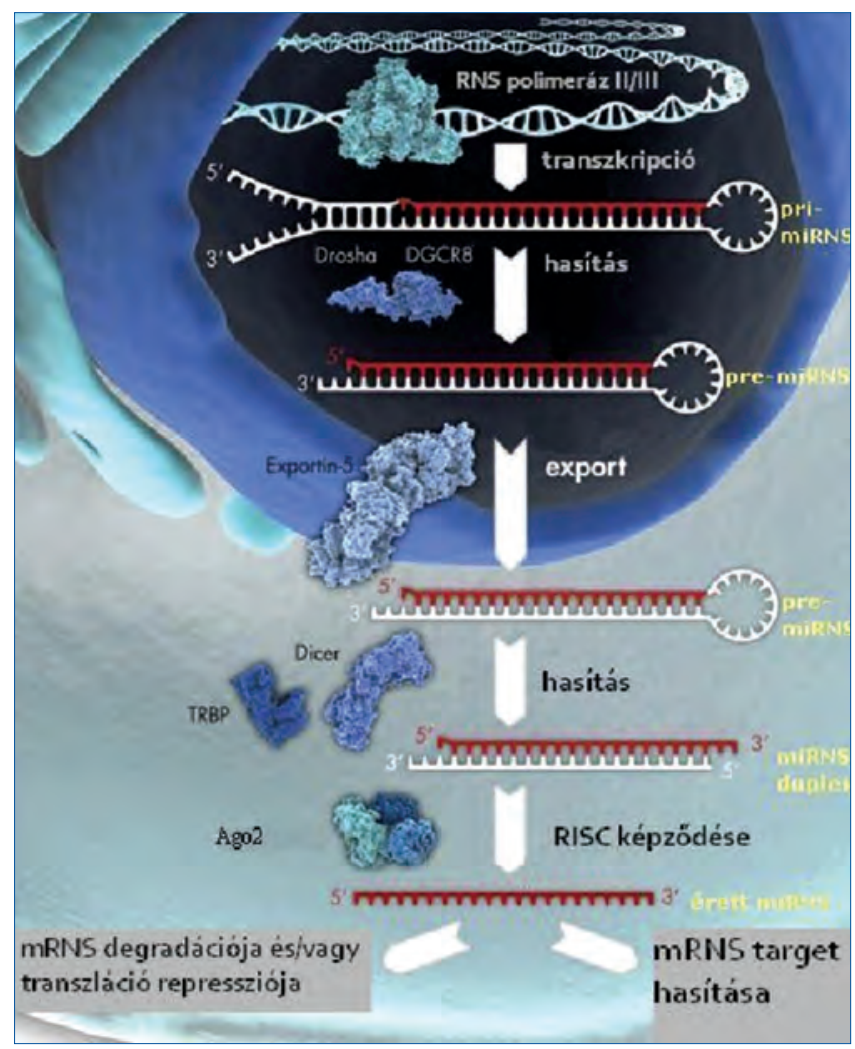

szuppresszorként vagy onkogénként viselkedve jelentősen hozzájárulnak a tumoros folyamatokhoz (1-3). Ezt a feltételezést az is alátámasztja, hogy a miR-t kódoló gének gyakran sérülékeny helyeken, olyan kromoszóma-régióban találhatóak, amelyek pontmutáción, amplifikáción, transzlokáción estek át tumorokban (1-4).

\section{A miR-ek biogenezise és általános jellemzésük}

Az érett miR-ek képződése többlépcsős folyamat. A miR-ek biogenezise a nucleusban kezdődik, ahol génjeikből RNSpolimeráz enzim segítségével íródnak át. Az RNS-polimeráz II függő transzkripcióban úgynevezett "hajtúkanyar” szerkezetü, kettős szálú primer miR (pri-miR) képződik. Ezután az RNáz-III aktivitású Drosha enzimből és DGCR8 (DiGeorge syndrome critical region gene 8) fehérjékből álló komplex alakítja tovább őket kisebb, körülbelül 70 nukleotid hosszú prekurzor miRekké (pre-miR) (1-3) (1. ábra).

A következő lépésben a sejtplazmába szállítódnak Exportin 5 transzport fehérje által, ahol további átalakításokon mennek keresztül egy enzim, az RNáz-III enzim, vagy az úgynevezett Dicer és ennek kofaktora TRBP (TAR RNA binding protein) segítségével. Ekkor 19-25 nukleotid nagyságú miR-duplexek képződnek. Ezek közül az egyik miR szál degradálódik és létrejön az érett miR. Az Ago 2 (Argonauta fehérje 2) proteinhez kötődve egy miR-RISC komplexbe (RISC=RNS indukálta csendesítő komplex) kerül, amelynek segítségével kötődni tud a célba vett (target) mRNS-hez (1-3) (1. ábra).

\section{A miR-ek szerepe a vesetumorok patomechanizmusában}

Ahogyan már korábban is említésre került, a miR-ek a sejtek különböző élettani folyamatait befolyásolják. Nagy szerepet kapnak a sejt növekedésében és fejlődésében, differenciációjában, és malignus transzformációjában egyaránt, ezáltal érintve a tumorok kialakulásának folyamatát (1, 4-6). Bonyolult jelátviteli folyamatokat és a sejtciklus különböző szakaszait szabályozzák funkcionálisan kulcs protoonkogén és tumorszuppresszor célmolekulákra hatva $(3,4)$. Funkciótól függően expressziójuk kóros elváltozása sejtburjánzáshoz vagy adott esetben fokozott apoptózishoz vezet (1-3). Számos daganat esetén mutattak ki az adott tumorra jellemző miR expressziós mintázatot, amely sok esetben segíthet a daganat osztályzásában és a prognózis elörejelzésében is ( 2 , $4,5)$.

A miR-ek tumorgenezisben betöltött szerepét kísérleti eredmények is igazolják. Tumoros szövetmintákat összehasonlítva normálmintákkal, miR-ek aberráns kifejeződését vagy deregulációját figyelték meg tumor kialakulása és fejlődése esetén (2, 3). Több irodalom szerint a miR-ek gátolni képesek a tumorképződésben szerepet játszó géneket a transzláció folyamatának befolyásolása révén $(2,3,4)$. Egyetlen miR tíz vagy akár száz különböző célgénre is hatással lehet. Génregulátorok egy 
csoportjának is tekinthetjük őket (1, 3). Karcinogenezisben betöltött szerepükre utalhat az is, hogy sok miR-t kódoló gén olyan kromoszomális régiókban található, amelyek aberráns elváltozása jellemző egyes daganat-típusokra (2, 3, 5-7).

A miR-ek szerepét alapvető fontosságúnak találták a vese múködésének és homeosztázisának tekintetében is. Expressziós szintjük aberráns elváltozása szöveti fibrózist és egyéb negatív irányú változást eredményezhet (4-7). Különböző miR expressziós paneleket vizsgálva megállapították, hogy segítségükkel megkülönböztethető a tumoros szövet a normál veseszövettől, így vesedaganatok esetén potenciális diagnosztikai eszközök lehetnek. Egyes tanulmányok szerint a malignus és a nem malignus esetek a miR-ek expresszió alapján jól elkülöníthetők. Az irodalomban már eddig is jó néhány tanulmány olvasható a világossejtes vesekarcinóma patomechanizmusában résztvevő miR-ek expressziós mintázatának vizsgálatáról is (8-11). További vizsgálatok pedig jelentősen növelhetik a világossejtes vesekarcinóma miR-expressziós profiljának szenzitivitását és specificitását ezáltal egy új diagnosztikai, prognosztikai módszert is létrehozva (8-11).

\section{A vesetumorokban leggyakrabban előforduló miR-ek}

Az utóbbi években a kutatók számtalan olyan erőfeszítést tettek annak érdekében, hogy a miR-ek és ezek specifikus targetjeinek a szintje mérhető legyen a vesedaganatos betegek szövetmintáiban és szérumában egyaránt, ezáltal lehetővé téve funkcionális elemzésüket (7-10). Microarray alapú vizsgálatok szerint vesekarcinómában (renal cell carcinoma: RCC) már eddig is több különböző upregulált és downregulált miR-t azonosítottak (11). Nem malignus világossejtes vesekarcinóma szövetben figyelemre méltó a miR-16, -452, -224, - 155 és 210-es csoport, amely többszörös emelkedést (2, 7 vagy akár 23-szoros) mutatott. A miR-200b, -363, -429,-200c, -514 és a -141 esetében inkább csökkenés (4,8 vagy akár 138-szo- ros) volt tapasztalható $(9,10)$. Gotardo és munkatársai által végzett microarray elemzés szerint a miR-28, -185, -27 és a let-7f-2 jelentősen upreguláltnak mutatkozott malignus világossejtes vesekarcinómában (clear cell renal cell carcinoma: ccRCC) a normálszövethez képest $(9,11)$. Más vizsgálatok eredményei szerint pedig a miR-34a, -224 és a -21-es mutatott túltermelődést a tumoros szövetben. Az eddig említett miR-ekre jelentős különbségek adódtak egy-egy RCC-altípus vonatkozásában is, többek között a ccRCC, valamint a papilláris (pRCC) altípusokat is beleértve. A magas miR-21 expresszió előrehaladottabb patológiai stádiummal és magasabb grádussal is korrelált (9-12).

Eddigi vizsgálatok szerint a metasztatikus és a nem metasztatikus vesetumoros eseteket illetően jelentős mintázatbeli eltérés főkképpen a következő miR-eknél mutatkozott: miR$451,-221,-30 a,-10 b$ és a $-29 a(12-14)$. A let-7 csoportba tartozó miR-30c- és a miR-26a jelentős csökkenést mutatott az igen agresszív metasztatikus tumoroknál (9, 12-14). Redova és munkatársai körülbelül 30 olyan miR-t azonosítottak, amelyek eltérő módon expresszálódtak az egészséges és a tumoros esetekben. Ezek közül 19 különböző miR jelentősen upregulált volt, míg másik 11 miR inkább downreguláltnak mutatkozott az RCC-ben szenvedő betegeknél $(9,14)$. (A humán vesekarcinómában és sejtvonalakban leggyakrabban előforduló up- és downregulált miR-eket az 1-2. táblázat foglalja össze). Egy másik tanulmány szerint, a miR-34, -21, valamint a -224 overexpressziót mutatott, a miR-141 pedig downregulált volt az RCC-s betegek szérumában $(9,15,16)$. A vesetumoros betegek szérumában a miR-21, miR-221 és a miR-222 viszont emelkedett volt az egészséges kontrollhoz képest (9, $11,12,15)$. A metasztázist mutató esetekben is a miR-221 jelentősebb túltermelődést mutatott a metasztázist nem mutató RCC-s betegek szérumához viszonyítva $(9,11,12,13,15)$. Mindezen vizsgálatok alapján elmondható, hogy a különböző miR-ek szintje igen eltérő RCC-ben, amely feltehetően magának a betegségnek lehet a következménye.

\section{TÁBLÁZAT: A HUMÁN VESEKARCINÓMÁBAN ÉS SEJTVONALAKBAN LEGGYAKRABBAN ELŐFORDULÓ DOWNREGULÁLT MIR-EK}

\begin{tabular}{|c|c|c|c|c|}
\hline miR-ek & Előfordulás & Funkció & Targetgén & Referenciák \\
\hline miR-34 a & RCC-szövet, sejtvonal & Tumorszuppresszor & c-Met, c-MYC, Notch1 & 34 \\
\hline miR-141 & RCC-szövet & Tumorszuppresszor & CDC25B & $16,21,30$ \\
\hline miR-145 & RCC-szövet & Tumorszuppresszor & ADAM17, ANGPT2 NEDD9 & 9 \\
\hline miR-199a-3p & RCC-szövet, sejtvonal & Még nem teljesen bizonyított & c-Met & 9,32 \\
\hline miR-200c & RCC-szövet & Még nem teljesen bizonyított & ZEB1 & 9,10 \\
\hline miR-217 & RCC-szövet & Tumorszuppresszor & Még nem teljesen bizonyított & $18,19,23$ \\
\hline miR-1826 & RCC-szövet & Tumorszuppresszor & B-katenin, MEK1 & 9,24 \\
\hline \multicolumn{5}{|c|}{$\begin{array}{l}\text { (CDC25B: cell division cycle 25B, ADAM17: ADAM metallopeptidáz domain 17, ANGPT2: angiopoietin 2, C-MET: hepatocyte growth factor re- } \\
\text { ceptor, C-MYC: egy regulátor gén, amely transzkripciós faktort kódol, MEK1: mitogen-activated protein kinase kinase 1, Notch1: notch1 (egy } \\
\text { transzmembrán receptort kódoló humán gén), NEDD9: neural precursor cell expressed, developmentally down-regulated 9, ZEB 1: zinc finger } \\
\text { E-box binding homeobox 1, ZEB2: zinc finger E-box binding homeobox 2) }\end{array}$} \\
\hline
\end{tabular}


2. TÁBLÁZAT: A HUMÁN VESEKARCINÓMÁbAN ÉS SEJTVONALAKBAN LEGGYAKRABBAN ELŐFORDULÓ UPREGULÁLT MIR-EK

\begin{tabular}{|c|c|c|c|c|}
\hline miR-ek & Előfordulás & Funkció & Targetgén & Referenciák \\
\hline let-7f -2 & RCC-szövet & Onkogén & Még nem teljesen bizonyított & 9,11 \\
\hline miR-21 & RCC-szövet, sejtvonal & Onkogén & PDCD4, TPM1, PTEN, TIMP3 & 9,12 \\
\hline miR-23b-3p & RCC-szövet, sejtvonal & Még nem teljesen bizonyított & PTEN & $12,25,27$ \\
\hline miR-23b & RCC-szövet, sejtvonal & Onkogén & POX & 9,25 \\
\hline miR-155 & RCC-szövet, sejtvonal & Onkogén & BACH1 & $9,17,35$ \\
\hline miR-210 & Sejtvonal & Még nem teljesen bizonyított & E2F3 & 9,20 \\
\hline miR-224 & ccRCC-szövet & Még nem teljesen bizonyított & DIO1 & 9 \\
\hline miR-590-5p & ACHB,786-O sejtek & OncomiR & PBRM1 & 9 \\
\hline
\end{tabular}

\section{A miR-ek, mint biomarkerek és lehetséges diagnosztikai szerepük}

Jelenlegi tanulmányok alapján számtalan, a különböző RCC-altípusokra specificitást mutató, eltérő módon szabályozott miR tûnik alkalmasnak arra, hogy diagnosztikai szerepe legyen a jövőben a vesetumorokat illetően. A ccRCC normálvesétől történő elkülönítésében lehetséges biomarkerként említhető a miR-141, amely egyidejüleg jelentős tumorszuppresszor szerepet tölthet be a ccRCC fejlődésében és a metasztázis szabályozásában is $(9,16)$. A miR-141 és a miR-155 expressziója eddig a vizsgált veseminták 97\%-ánál tette lehetővé a pontos klasszifikációt $(9,17)$. Ezen túlmenően a miR-141 és 200b-vel kiegészített miR panel az RCC-nek a normál veseszövettől, valamint az oncocytomának az RCC-től történő pontos elkülönítését segítette, és a kromofób típus is jól elkülöníthető volt az oncocytomától $(9,16,18)$. Faragalla és munkatársai kimutatták, hogy a miR-21 expressziója alapján 90\%-os specifitással és 83\%-os érzékenységgel a ccRCC- és a pRCC-típusok megkülönböztethetők a kromofób (chRCC) típustól és az oncocytomától is $(9,12)$. Youssef és munkatársai egy egyedi osztályozási rendszert állítottak fel RCC-típusok elkülönítésére. Az általuk kidolgozott rendszer eredményesen múködik a különböző RCC-típusok azonosításában. Így, a normál RCC-re 97\%-os, a ccRCC-re 100\%-os, a pRCC-re nézve 97\%-os, az oncocytoma esetében pedig 100\%-os érzékenységgel bír a chRCC-től való elkülönítésében $(9,18,19)$.

Ahogyan már az előzőekben említésre került, a vesetumoros betegekben az extracelluláris miR-koncentráció a szérumban és vizeletben is abnormális értéket mutathat. Így, például a miR378 szérumban emelkedhet az RCC-ben szenvedő betegeknél, míg a miR-451-nek ezzel ellentétben csökkent szintje jellemző az egészséges kontrollhoz képest. Az említett két miR együttes vizsgálata $81 \%$-os érzékenységgel és $83 \%$-os specificitással teszi lehetővé a vesetumoros betegek diagnosztizálását $(9,14)$.
Mint potenciális biomarker kiemelendő még a miR-1233, amely szérumban jelentős emelkedést mutat (érzékenység: 77,4\%, specificitás: 37,6\%) (9). Korai stádiumú RCC-ben a miR-210 szintjében volt megfigyelhető abnormális emelkedés az egészséges kontrollhoz képest, ez esetben a módszer érzékenysége 81,0\%, specificitása pedig 79,4\% adódott (20). Az RCC-betegek vizeletében magas miR-15a szint volt mérhető, amely szinte egyáltalán nem volt jelen oncocytomában, más típusú tumorokban, valamint a vizeletkiválasztó rendszer gyulladásos megbetegedéseiben sem (9).

Noha az eredmények elfogadása érdekében, a módszer rutinban történő bevezetéséhez további széles spektrumú és megerősítő vizsgálatok szükségesek, a módszer magas diagnosztikai pontossága alapján elmondható, hogy a jövőben a miR-ek új generációbeli biomarkerek lehetnek a vesetumor diagnosztizálásában, valamint a szövettani altípusok elkülönítésében is $(3,6,7,8)$.

\section{A miR-ek lehetséges prognosztikai szerepe}

Az irodalom szerint a vesetumorokban vizsgált aberráns miRexpresszió összefüggést mutathat a túléléssel, a betegség klinikai státuszával, a patológiai grádussal, a betegség kiújulásával és a metasztázissal is. Eddigi kísérleti adatok alapján, egyes kismértékben expresszálódó miR-ek (miR-187, -215, -217, - 155 és -1826) rossz prognózisra utalnak, túltermelődésük esetén rövid túlélési idő és korai kiújulás volt tapasztalható (21-24). Más tanulmányok szerint a miR-143,-26a, -145,-10b, - 195 és a -126 expressziója jóval alacsonyabb a relapszust mutató RCC-esetekben $(9,10)$. A legalacsonyabb expressziós szintje pedig ezeknek a miR-eknek a primer metasztatikus tumorokban volt megfigyelhető $(9,10)$. Kaplan-Meier-analízis alapján úgy találták, hogy a miR-127-3p, -145 és a -126 expresszója szignifikánsan korrelált a metasztázist nem mutató betegek 
relapszusmentes túlélésével $(9,10)$. A pozitív miR-21, $-23 b-3 p$, $-100,-630$ expresszió minden esetben alacsony túlélési időt és korai kiújulást is jelentett $(12,25-27)$.

Az RCC-ben jelentkező metasztázis nagyon általános dolog, éppen ezért egyre több tanulmány foglalkozik a miR-ek metasztázist előrejelző klinikai szerepével. Példaként említhetők a miR-10b, -139-5p, -130b és a -199b-5p, amelyek expressziója jelentős összefüggést mutat az RCC-ben fellépő metasztázissal és a betegség korai kiújulásával is (28). A miR-106b expressziós szintje jelentősen alacsonyabb volt azokban a betegekben, akiknél korai metasztázis volt megfigyelhető közvetlenül a nephrestomiát követően (29).

Plazmában, a magas expressziót mutató miR-221 rossz túlélést jelentett, míg a csökkent miR-187 szint magasabb Grade-re és elörehaladottabb klinikopatológiai státuszra utalt $(15,21)$. A magas miR-187 szinttel rendelkező összes beteg 5 éves túlélést mutatott, míg a miR-187 alacsony szintje esetén a betegeknek mindössze 42\%-ánál volt tapasztalható 5 éves túlélés $(9,21)$.

\section{A miR-ek terápiában betöltött lehetséges szerepe}

A molekuláris célzott terápia jelenleg az egyik leghatékonyabb módszer az RCC-betegek kezelésében, amelynek felállításához fontos információ lehet a terápia iránti érzékenység előrejelzése. A miR-eknek egyre nagyobb prediktív szerep tulajdonítható ezen a téren is, ezért egyre hangsúlyosabbak az ebben a témában végzett kutatások is.

Egyik tanulmány szerint a miR-141 a sunitinib kezelésre nehezen reagáló eseteknél jelentősen downreguláltnak mutatkozott $(9,30)$. Egy másik elemzés alapján a miR-942 volt a legpontosabb előrejelzője a sunitinib érzékenységnek (31). Magas miR-942, -628-5p, -133a és -484 expressziója jelentősen öszszefügg a metasztatikus RCC-esetek előrehaladásával, valamint a túléléssel is, amit az is igazol, hogy ezek a miR-ek a sunitinib rezisztens CAKI-2 humán RCC-sejtvonalban is abnormális mértékben expresszálódtak az érzékeny sejtvonalhoz képest $(9,31)$.

A közelmúltban lett igazolva a miR-199a-3p sejtproliferációt gátló és a sejtciklus G1 fázisát blokkoló tulajdonsága a CAKI-1 RCC-sejtvonalban (32). A miR-138 RCC-sejtvonalakba történő transzfekciója megváltozott sejtmorfológiához, gátolt sejtmigrációhoz és -invazivitáshoz vezetett $(9,33)$. A miR-424 és a miR-381 kombinált alkalmazásával a fokozott sejtproliferációgátlás, felfüggesztett G2/M-fázis és indukált apoptózis volt ta- pasztalható. Említhető még a miR-205, amelynek transzfekciója in vivo körülmények között is jelentősen gátolja a tumorsejtek proliferációját (9). A miR-34 viszont egyúttal a sejtproliferáció gátlását, az érképződés folyamatát és a metasztázist is befolyásolja a CD44 targetálása révén (34). A miR-210 csendesítésével az ACHN és a CAKI-2 humán RCC-sejtvonalak életképessége csökkent, valamint a tumorsejtek felhalmozódása a G2-fázisba tolódott el (34, 35). A miR-23b-3p csendesítésével a PTEN (foszfatáz és tenzin homológ) gén indukálódik, míg ezzel összhangban a PI3-kináz (foszfatidil-inozitol4,5-bifoszfát-3-kináz), a PK-B (protein kináz-B) és IL-32 aktivitás csökken, amely csökkent invazivitáshoz vezet és apopotózist indukál (25). A miR-155 szuppressziója specifikus targetek révén gátolja a sejtproliferációt és a migrációt, valamint apoptózist vált ki (35).

Preklinikai vizsgálatokban a miR-en alapuló terápia más terápiás stratégiákkal együtt is használható. Megemlíthető a miR381, amely fokozza a 786-O humán RCC-sejtvonal érzékenységét az 5-FU-val szemben, ami emelkedett Cdc2 (ciklin-dependens-kináz-2) aktivitáson alapul (36). Egy másik tanulmány szerint, a miR-185 a besugárzás által kiváltott apoptózist és a proliferáció gátlást is aktiválja (37). Megjegyzendő, hogy a korábban már említett miR-141 a sejtek hipoxiás közegben tapasztalható érzékenységére is kihatással van (30).

Összességében véve elmondható, hogy a miR-ek expresszója epigenetikai szinten szabályozott. Éppen ezért adott gének expresszójának epigenetikai szabályozása jelentős szerepet tölt be az adott miR-ek megjelenésében is (38).

\section{Megbeszélés}

A daganatos betegségek olyan heterogén csoportot képviselnek, amelyek terápiájára jelenleg nincs megnyugtatóan hatékony gyógykezelés $(3,6,7)$. Számos tanulmány igazolja, hogy a miR-ek mélyebb ismerete hatással van az RCC patogenezisének jobb megértésére. Ezek a kis molekulák újabb potenciális biomarkereknek az eshetőségét vetik fel, amelyek bővítésével a tumordiagnosztikai, a prognosztikai - predikciós, valamint a terápiás lehetőségek is egyaránt bővülnek. Jelen ismeretek szerint a kutatók meggyőződése, hogy megfelelő miR-alapú terápiával a személyre szabott terápia egyre inkább tovább fejlődhet és hatékonyabbá válhat. Remélhetőleg, a miR-ek mint új célpontok olyan terápiás utakat is megnyithatnak a jövőben, amelyek révén a gyógyszer-rezisztencia még inkább legyőzhető lesz és a daganatterápia eredményesebbé tehető majd $(39,40)$. 


\section{Irodalom}

1. Rooij EV. The Art of MicroRNA Research. Circ Res 2011; (108): 19234. https://doi.org/10.1161/CIRCRESAHA.110.227496

2. Wang J, Zhang KY, Liu SM, et al. Tumor - Associated circulating MicroRNAs as biomarkers of cancer. Molecules 2014; (19): 19121938. https://doi.org/10.3390/molecules 19021912

3. Seliger B, Jasinski S, Dressler SP, et al. Linkage of microRNA and proteome - based profiling data sets: A perspective for the priorization of candidate biomarkers in renal cell carcinoma? J. Proteome Res 2011; (10): 191-199. https://doi.org/10.1021/pr1011137

4. Zhang B, Pan X, Cobb GP, Anderson TA. MicroRNAs as oncogenes and tumor suppressors. Developmental Biology 2007; (302): 1-12. https://doi.org/10.1016/j.ydbio.2006.08.028

5. Gottardo F, Liu CG, Ferracin M, et al. Micro - RNA profiling in kidney and bladder cancer. Urologic Oncology: Seminars and Original Investigations 2007; (25): 387-392.

6. White NMA, Bao TT, Grigull J, et al. MiRNA profiling for clear cell renal cell carcinoma: biomarker discovery and identification of potential controls and consequences of miRNA disregulation. The Journal Of Urology 2011; (186): 1077-1083. https://doi.org/10.1016/ j.juro.2011.04.110

7. Grange C, Collino F, Tapparo M, et al. Oncogenic microRNAs and renal cell carcinoma. Frontier in Oncology 2014; (4): 49.

8. Liu H, Brannon AR, Reddy AR, et al. Identifying mRNA targets of microRNA dysregulated in cancer: with application to clear cell renal cell carcinoma. BMC System Biology 2010; (4): 51-53. https://doi.org/10.1186/1752-0509-4-51

9. Li M, Wang $Y$, Song $Y$, et al. MicroRNAs in renal cell carcinoma: a systematic review of clinical implications. Oncol Rep 2015; 33(4): 1571-8. https://doi.org/10.3892/or.2015.3799

10. Slaby O, Redova M, Poprach A, et al. Identification of MicroRNAs associated with early relapse after nephrectomy in renal cell carcinoma patients. Genes Chromosomes Cancer 2012; 51(7): 707-16. https://doi.org/10.1002/gcc.21957

11. Selliti DF, Doi SQ. MicroRNAs in renal cell carcinoma. Microrna 2014 4(1): 26-35. https://doi.org/10.2174/2211536604666150713105247

12. Faragalla $H$, Youssef $Y M$, Scorilas $A$, et al. The clinical utility of miR-21 as a diagnostic and prognostic marker for renal cell carcinoma. J Mol Diagn 2012; (4): 385-92. https://doi.org/10.1016/ j.jmoldx.2012.02.003

13. Heinzelmann J, Henning B, Sanjmyatav J, et al. Specific miRNA signatures are associated with metastasis and poor prognosis in clear cell renal cell carcinoma. World J Urol 2011; 29(3): 367-73. https:// doi.org/10.1007/s00345-010-0633-4

14. Redova M, Poprach A, Nekvindova J, et al. Circulating miR-378 and miR-451 in serum are potential biomarkers for renal cell carcinoma. J Transl Med 2012; 10: 55. https://doi.org/10.1186/1479-5876-10-55

15. Teixeira AL, Ferreira M, Silva J, et al. Higher circulating expression levels of miR-221 associated with poor overall survival in renal cell carcinoma patients. Tumour Biol 2014; 35(5): 4057-66. https:// doi.org/10.1007/s 13277-013-1531-3

16. Chen $X$, Wang $X$, Ruan $A$, et al. miR-141 is a key regulator of renal cell carcinoma proliferation and metastasis by controlling EphA2 expression. Clin Cancer Res 2014; 20(10): 2617-30. https://doi.org/ 10.1158/1078-0432.CCR-13-3224

17. Shinmei S, Sakamoto N, Goto K, et al. MicroRNA-155 is a predictive marker for survival in patients with clear cell renal cell carcinoma. Int J Urol 2013; 20(5): 468-77. https://doi.org/10.1111/j.1442-2042. 2012.03182.x

18. Silva-Santos RM, Costa-Pinheiro $P$, Luis $A$, et al. MicroRNA profile: a promising ancillary tool for accurate renal cell tumour diagnosis. $\mathrm{Br}$ J Cancer 2013; 109(10): 2646-53. https://doi.org/10.1038/bjc.2013.552

19. Youssef YM, White NM, Grigull J, et al. Accurate molecular classification of kidney cancer subtypes using microRNA signature. Eur Urol 2014; 59(5): 721-30. https://doi.org/10.1016/j.eururo. 2011.01.004

20. Iwamoto $H$, Kanda $Y$, Sejima T, et al. Serum miR-210 as a potential biomarker of early clear cell renal cell carcinoma. Int J Oncol 2014; 44(1): 53-8.

21. Zhao J, Lei T, Xu C, et al. MicroRNA-187, down-regulated in clear cell renal cell carcinoma and associated with lower survival, inhibits cell growth and migration though targeting $\mathrm{B} 7-\mathrm{H} 3$. Biochem Biophys Res Commun 2013; 438(2): 439-44. https://doi.org/10.1016/ j.bbrc.2013.07.095
22. Khella HW, Bakhet M, Allo G, et al. miR-192, miR-194 and miR-215: a convergent microRNA network suppressing tumor progression in renal cell carcinoma. Carcinogenesis 2013; 34(10): 2231-9. https://doi.org/10.1093/carcin/bgt 184

23. Li H, Zhao J, Zhang JW, et al. MicroRNA-217, down-regulated in clear cell renal cell carcinoma and associated with lower survival, suppresses cell proliferation and migration. Neoplasma 2013; 60(5): 511-5. https://doi.org/10.4149/neo_2013_066

24. Hirata $\mathrm{H}$, Hinoda $\mathrm{Y}$, Ueno $\mathrm{K}$, et al. MicroRNA-1826 directly targets beta-catenin (CTNNB1) and MEK1 (MAP2K1) in VHL-inactivated renal cancer. Carcinogenesis 2012; 33(3): 501-8. https://doi.org/ 10.1093/carcin/bgr302

25. Zaman MS, Thamminana S, Shahryari V, et al. Inhibition of PTEN gene expression by oncogenic miR-23b-3p in renal cancer. PLoS One 2012; 7(11): e50203. https://doi.org/10.1371/journal.pone.0050203

26. Wang G, Chen L, Meng J, et al. Overexpression of microRNA100 predicts an unfavorable prognosis in renal cell carcinoma. Int Urol Nephrol 2013; 45(2): 373-9. https://doi.org/10.1007/s11255-012-0374-y

27. Zhao JJ, Chen PJ, Duan RQ, et al. Up-regulation of miR-630 in clear cell renal cell carcinoma is associated with lower overall survival. Int J Clin Exp Pathol 2014; 7(6): 3318-23.

28. Wu X, Weng L, Li X, et al. Identification of a 4 microRNA signature for clear cell renal cell carcinoma metastasis and prognosis. PLoS One 2012; 7(5): 45-48. https://doi.org/10.1371/journal.pone.0035661

29. Slaby O, Jancovicova J, Lakomy R, et al. Expression of miRNA-106b in conventional renal cell carcinoma is a potential marker for prediction of early metastasis after nephrectomy. J Exp Clin Cancer Res 2010; 29: 90. https://doi.org/10.1186/1756-9966-29-90, https:// doi.org/ 10.1186/ 1756-9966-29-105

30. Berkers J, Govaere O, Wolter P, et al. A possible role for microRNA141 down-regulation in sunitinib resistant metastatic clear cell renal cell carcinoma through induction of epithelial-to-mesenchymal transition and hypoxia resistance. J Urol 2013; 189(5): 1930-8. https://doi.org/10.1016/j.juro.2012.11.133

31. Prior C, Perez-Gracia JL, Garcia-Donas J, et al. Identification of tissue microRNAs predictive of sunitinib activity in patients with metastatic renal cell carcinoma. PLoS One 2014; 9(1). https://doi.org/ $10.1371 /$ journal.pone. 0086263

32. Huang J, Dong B, Zhang J, et al. miR-199a-3p inhibits hepatocyte growth factor/c-Met signaling in renal cancer carcinoma. Tumour Biol 2014; 35(6): 5833-43. https://doi.org/10.1007/s 13277-014-1774-7

33. Yamasaki T, Seki N, Yamada Y, et al. Tumor suppressive microRNA 138 contributes to cell migration and invasion through its targeting of vimentin in renal cell carcinoma. Int J Oncol 2012; 41(3): 805-17.

34. Yu G, Li H, Wang J, Gumireddy K, et al. miRNA-34a suppresses cell proliferation and metastasis by targeting CD44 in human renal carcinoma cells. J Urol 2014; 192(4): 1229-37. https://doi.org/10.1016/ j.juro.2014.05.094

35. Li S, Chen T, Zhong Z, et al. MicroRNA-155 silencing inhibits proliferation and migration and induces apoptosis by upregulating BACH1 in renal cancer cells. Mol Med Rep 2012; 5(4): 949-54.

36. Chen B, Duan L, Yin G, et al. miR-381, a novel intrinsic WEE1 inhibitor, sensitizes renal cancer cells to 5 -FU by up-regulation of $\mathrm{Cdc} 2$ activities in 786-O. J Chemother 2013; 25(4): 229-38. https://doi.org/ 10.1179/1973947813Y.0000000092

37. Wang J, He J, Su F, Ding N, Hu W, Yao B, Wang W, Zhou G. Repression of ATR pathway by miR-185 enhances radiation induced apoptosis and proliferation inhibition. Cell Death Dis 2013; 4: e699. https:// doi.org/10.1038/cddis.2013.227

38. Schiffgen $M$, Schmidt $D H$, von Rücker $A$, et al. Epigenetic regulation of microRNA expression in renal cell carcinoma. Biochem Biophys Res Commun 2013; 436(1): 79-84. https://doi.org/10.1016/ j.bbrc.2013.05.061

39. Lin J, Horikawa $Y$, Tamboli $P$, et al. Genetic variations in microRNArelated genes are associated with survival and recurrence in patients with renal cell carcinoma. Carcinogenesis 2010; 31(10): 1805-2. https://doi.org/10.1093/carcin/bgq168

40. Sekar VT, Mohanram RK, Foygel K, et al. Therapeutic Evaluation of microRNAs by Molecular Imaging. Theranostics 2013; (3): 964-985. https://doi.org/10.7150/thno.4928 